\title{
PENGUKURAN KINERJA VOIP DENGAN CODEC G.711 $\mu$, G.711a DAN G.729 DI MEDIA TRANSMISI NIRKABEL BERBASIS SIP DAN IAX
}

\author{
Putu Sintia Susiani Pande ${ }^{1}$, Pande Ketut Sudiarta ${ }^{2}$, I Made Oka Widyantara ${ }^{3}$ \\ ${ }^{1,2,3}$ Program Studi Teknik Elektro, Fakultas Teknik, Universitas Udayana \\ Email : sintiasusianipande@gmail.com ${ }^{1}, \underline{\text { sudiarta@unud.ac.id }{ }^{2}}=\underline{\text { oka.widyantara@unud.ac.id }{ }^{3}}$ \\ Abstrak \\ Voice over Internet Protocol (VoIP) adalah teknologi yang dapat mengirimkan data yang \\ berbentuk real time dengan jaringan berbasis IP (Internet Protocol). Pada teknologi VoIP dengan \\ jaringan nirkabel memiliki beberapa masalah yang menyebabkan kinerja pada jaringan menjadi \\ bervariasi karena adanya QoS (Quality of Service) meliputi delay, jitter, packet loss dan MOS yang \\ mempengaruhi jaringan nirkabel. Penelitian ini menggunakan codec G.711 $\mu$, G.711a dan G.729 \\ berbasis server SIP dan IAX pada jaringan nirkabel yang kemudian hasil QoS dari masing - masing \\ codec dibandingkan dengan standarisasi ITU-T yang menjadi acuan apakah jaringan tersebut bagus \\ atau tidak sehingga nantinya dapat direalisasikan dikampus. Pada hasil penelitian, QoS pada wireless \\ IEEE 802.11 b memiliki hasil yang linear, sedangkan QoS pada wireless yang terbebani VoIP memiliki \\ hasil fluktuatif karena penggunaan codec pada VolP yang mana masing-masing codec memiliki besar \\ bitrate dan teknik pengkodean yang berbeda dan merupakan ciri jaringan nirkabel. Perbandingan QoS \\ ketiga codec menghasilkan codec G.711 dengan kualitas QoS terbaik dikarenakan codec G.711 \\ memiliki bitrate yang sesuai dengan standar komunikasi suara yaitu 64 kbps dan menggunakan teknik \\ pengkodean suara yang sesuai dengan teknik pengkodean sinyal digital yaitu teknik PCM (Pulse \\ Code Modulation).
}

Kata Kunci : Codec, Nirkabel, QoS, VolP

\section{Abstract}

Voice over Internet Protocol (VoIP) is a technology that can send real-time data with IP-based networks (Internet Protocol). In VolP technology with wireless network has several problems that cause the performance of the network to be varied due to the QoS (Quality of Service) include delay, jitter, packet loss and MOS that affect the wireless network. This research uses G.711 $\mu, G .711 a$ and G.729 codec based on SIP and IAX server on wireless network which then the QoS result from each codec compared with ITU-T standard which become the reference of whether the network is good or not so that later can realized on campus. In the research results, QoS on wireless IEEE 802.11 b has linear results, whereas QoS wireless in VolP has fluctuating results because the use of codecs in VolP on each codec has a large bitrate and different coding techniques and is a feature of wireless networks. The QoS comparison of three codecs produced the best G711 Q7S codecs because the G.711 codec has a bitrate that conforms to the 64 kbps voice communication standard and uses voice coding techniques that match the digital signal encoding technique of PCM (Pulse Code Modulation).

Keywords: Codec, QoS, VolP, Wireless

\section{PENDAHULUAN}

Hotspot Wi-Fi (Wireless Fidelity) di areal kampus biasanya dimanfaatkan sebagian mahasiswa untuk memenuhi kebutuhan perkuliahannya seperti mencari materi kuliah, ebook, jurnal dan masih banyak lagi. Adapula mahasiswa yang menggunakan salah satu fasilitas kampus ini untuk sekedar membuka media sosial mereka agar dapat melakukan komunikasi dengan teman ataupun keluarganya.

Wi-Fi (Wireless Fidelty) adalah teknologi penyedia akses internet yang memiliki bandwidth besar. Teknologi Wi-Fi bekerja pada standar jaringan IEEE 802.11 yang diterapkan oleh Komite Standar IEEE Wireless LAN [1]. 
VoIP merupakan fasilitas yang menyerupai telepon sehingga user bisa berbicara dengan user lain, tetapi dalam suatu jaringan internet. Suara dari user akan diubah ke bentuk kode digital dan dikirimkan dalam bentuk paket data [2].

Cara kerja yang digunakan untuk menentukan kualitas layanan pada teknologi jaringan telekomunikasi adalah QoS (Quality of Service). Quality of Service (QoS) adalah kemampuan untuk memberikan layanan pada jaringan dengan trafik data tertentu meliputi delay, jitter, packet loss dan MOS (Mean Opinion Score). Selain itu ada juga Received Signal Level dan Service Coverage Area [2], [3]. Pengukuran MOS menggunakan metode pengukuran objektif dengan mengandalkan parameter uji terukur (delay dan packet loss) [4].

Maka dari itu diperlukan analisis kinerja VoIP dengan codec G.711a, G.711 $\mu$ dan G.729 pada media transmisi nirkabel berbasis dua server, yaitu server SIP dan server IAX.

\section{KAJIAN PUSTAKA}

\subsection{Jaringan Nirkabel}

Jaringan nirkabel (wireless) adalah teknologi jaringan yang menggunakan media transmisi gelombang radio. Standarnya dibuat oleh konsorsium perusahaan produsen peranti W-LAN, Wireless Ethernet Communications Alliance untuk mempromosikan komparibilitas perangkat 802.11 [5].

\subsection{Voice Over Internet Protocol (VoIP)}

Voice over Internet Protocol (VoIP) adalah teknologi yang dapat mengirimkan data yang berbentuk real time dengan jaringan berbasis IP (Internet Protocol) [6].

Paket data VolP terdiri atas dua bagian, yaitu header dan payload. Header terdiri dari IP header, Real-time Transport Protocol, User Datagram Protocol (UDP) header, dan link header [7].

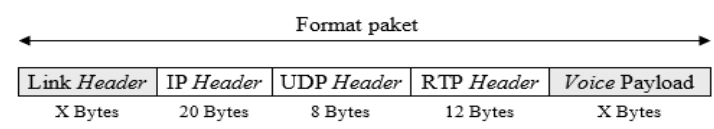

Gambar 1. Format Paket VolP (7)

Gambar 1 adalah paket data VolP yang akan melalui jaringan nirkabel. IP header berfungsi menyimpan informasi routing untuk mengirim paket data ke receiver. Tiap header IP bersamaan dengan tipe layanan atau Type of Service (ToS) yang memungkinkan paket tertentu seperti voice data yang non real time. UDP header memiliki ciri - ciri yaitu tidak menjamin packet akan sampai pada receiver sehingga UDP cocok digunakan pada voice real time application yang rawan terhadap delay dan latency [7].

\subsection{Codec G.711 dan G.729}

G.711 adalah international standarization pada kompresi voice data dengan mengaplikasikan teknik Pulse Code Modulation (PCM) dalam pengiriman suara. PCM mengubah sinyal analog menjadi sinyal digital dengan melakukan sampling 8000 kali/detik dan dikodekan dalam bentuk angka. Jarak antar sampel

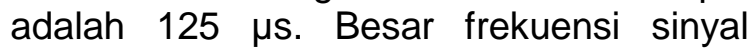
analog pada suatu percakapan adalah 300 $\mathrm{Hz}-3400 \mathrm{~Hz}$. PCM menggunakan 8 bit untuk melakukan pengkodean. Kecepatan pada laju transmisi didapatkan dengan mengkalikan 8000 sampel/detik dengan 8 bit/sampel, menjadi $64.000 \mathrm{bit} /$ detik. Bit rate $64 \mathrm{Kbps}$ ini adalah standarisasi dari pada transmisi satu channel telepon digital [8].

G.729 adalah pengkodean suara berjenis CELP yang menghasilkan kompresi sampai sebesar $8 \mathrm{Kbps}$. Codec ini digunakan saat bekerja pada sinyal digital yang dapat dicapai dengan filter bandwidth memakai keluaran sinyal analog [8].

\subsection{Server SIP dan IAX}

SIP (Session Initial Protocol) adalah suatu protocol signalling pada application layer yang berguna untuk building, modification, dan finishing dari pada suatu multimedia section dan dikaitkan pada satu atau lebih user. Multimedia section adalah pertukaran voice, video dan text data antar user. SIP dapat menyediakan layanan 
yang tidak langsung, namun SIP menyediakan pondasi yang digunakan protocol application lain untuk memberi service yang lebih lengkap untuk user, misal RTP (Real Time Transport Protocol) berfungsi untuk mentransfer real-time data, SDP (Session Description Protocol) berfungsi untuk deskripsi multimedia section, MEGACO (Media Gateway Control Protocol) berfungsi untuk melakukan percakapan dengan PSTN (Public Switch Telephone Network) [8].

IAX (Inter Asterisk Exchange ) adalah protocol yang simple berguna saat melewati Network Address Translation (NAT). Mini Frame (data frame berukuran kecil) dan Full Frame (data frame berukuran besar) dibawa diantara dua endpoint A dan B. Tiap haluan audio data dan frame video dari IAX Mini frame (frame $M)$ yang memiliki isi 4 byte header. Haluan ini disempurnakan dengan Full Frames (F Frames) secara teratur meliputi synchronization information. UDP berfungsi pada IAX untuk mengirimkan data audio dan video pada packet IAX audio yang terbagi atas 4 bagian, yaitu IP header, UDP header, IAX header dan IAX payload [9].

\subsection{Kualitas Layanan VoIP}

Quality of Service (QoS) adalah layanan yang disediakan pada suatu jaringan pada trafik data tertentu dalam berbagai bentuk teknologi. QoS tidak didapatkan langsung melalui infrastruktur yang ada, namun didapat langsung dengan mengaplikasikannya pada jaringan. Parameter yang digunakan sebagai ukuran kinerja suatu jaringan teknologi VoIP adalah antara lain [10]:

\subsubsection{Delay}

Delay adalah waktu tunda yang disebabkan oleh proses transmisi dari transmitter ke receiver. Besar delay maksimum sesuai dengan standarisasi ITU untuk voice application adalah $150 \mathrm{~ms}$, sedangkan delay maksimum dengan kualitas suara yang masih dapat diterima user adalah $250 \mathrm{~ms}$. Tabel 1 adalah standar delay menurut ITU-T G.114 [10].

Tabel 1. Parameter Delay ITU-T G.114 (9)

\begin{tabular}{|c|c|}
\hline Nilai Delay & Kualitas \\
\hline $0-150 \mathrm{~ms}$ & Baik \\
\hline $150-400 \mathrm{~ms}$ & Cukup, masih dapat diterima \\
\hline$>400 \mathrm{~ms}$ & Buruk, tidak dapat diterima \\
\hline
\end{tabular}

\subsubsection{Jitter}

Jitter adalah variasi waktu delay yang terjadi karena adanya interval periodic antar kedatangan data packet pada receiver. Data packet yang datang pada receiver dikumpulkan dalam jitter buffer selama waktu yang telah ditentukan sampai paket dapat diterima pada sisi penerima dengan urutan yang benar. Namun jitter tidak dihilangkan karena prosedur antrian yang terbaik tetap saja tidak dapat mengatasi semua kasus antrian. Tabel 2 adalah standar jitter menurut ITU-T [10].

Tabel 2. Standar Jitter ITU-T (10)

\begin{tabular}{|c|c|}
\hline Nilai Jitter & Kualitas \\
\hline $0-20 \mathrm{~ms}$ & Baik \\
\hline $20-50 \mathrm{~ms}$ & Cukup \\
\hline$>50 \mathrm{~ms}$ & Buruk \\
\hline
\end{tabular}

\subsubsection{Packet loss}

Packet loss adalah kegagalan transmisi paket data untuk mencapai penerima (receiver). Kegagalan paket tersebut dapat disebabkan oleh beberapa hal, yakni :

a) Terjadinya kelebihan pada trafik didalam jaringan

b) Adanya congestion pada jaringan,

c) Error pada media physic,

d) Kegagalan yang terjadi pada receiver yang disebabkan karena overflow pada buffer. 
Tabel 3 adalah standar packet loss menurut ITU-T [8].

Tabel 3. Standar Packet loss ITU-T (10)

\begin{tabular}{|c|c|}
\hline Packet loss & Kualitas \\
\hline $0-0.5 \%$ & Sangat Baik \\
\hline $0.5-1.5 \%$ & Baik \\
\hline $1.5 \%$ & Buruk \\
\hline
\end{tabular}

\subsubsection{Mean Opinion Score (MOS)}

Untuk mengukur kualitas layanan VolP, maka parameter yang akan dihitung adalah MOS (Mean Opinion Score). Karena prosesnya yang mengandalkan parameter uji terukur, maka hasil evaluasi ini biasa disebut dengan Objective MOS. Berdasarkan Rekomendasi ITU-T P.107, maka nilai MOS dapat diperoleh dengan terlebih dahulu menghitung $\mathrm{R}$ factor sebagai berikut [11]:

$R=94.2-I_{d}-I_{e f}$

Keterangan :

- $R$ factor : Nilai maksimum ITU - T

- I_d : Delay

- $I_{\text {ef }} \quad$ : Packet loss

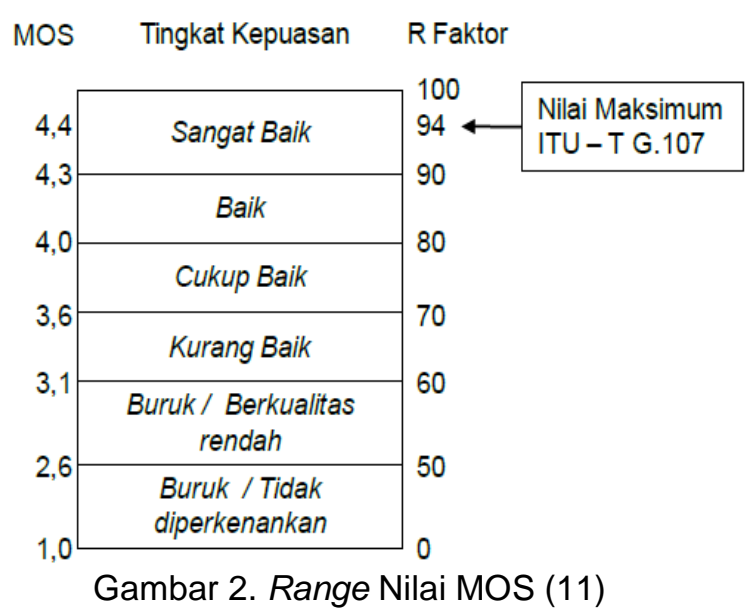

Untuk mengubah estimasi dari nilai $\mathrm{R}$ faktor kedalam MOS (ITU-T P.800) terdapat ketentuan sebagai berikut [12]:

- Untuk $\mathrm{R}<0$ maka MOS = 1

Kondisi ini menerangkan apabila delay total yang dihasilkan sangat besar dan hal tersebut membuat buruk pada kualitas VoIP dan tidak diperkenankan untuk diaplikasikan bahkan mulai $\mathrm{R}<50$ [12].

- Untuk R > 100 maka MOS $=4.5$

Persamaan ini untuk menerangkan kualitas yang paling bagus dari VolP itu sendiri karena prinsipnya nilai $R$ maksimum hanya 94.2. Untuk realitasnya yang dipakai adalah untuk persamaan seperti di bawah ini [12].

- Untuk $0<\mathrm{R}<100$ maka $\mathrm{MOS}=1+$ 0.035R + 7×10-6 R(R-MIN_R) [12].

- Nilai MIN_R yang biasa digunakan untuk perhitungan ini biasanya 50 seperti yang ditunjukkan pada standar VolP [12].

\subsection{FSL (Free Space Loss)}

Redaman ruang bebas atau free space loss merupakan penurunan daya gelombang radio selama merambat di ruang bebas. Nilai free space loss dihitung dengan persamaan di bawah ini [13]:

FSL $($ Free Space Loss $)=$ Tx Power - Tx cable loss

+ Tx antenna gain $+R x$ antenna gain $-R x$ cable loss

- Rx Sensitivity - Fade Margin

Untuk mencari jarak rambatan pada ruang bebas dapat menggunakan persamaan dibawah ini [13]:

$20 \log (d)=F S L-92,45-20 \log 10(f)$

\section{METODE PENELITIAN}

\subsection{Tahapan Penelitian}

\subsubsection{Skenario Penelitian Tanpa Beban VolP}

Skenario penelitian pada jaringan wireless IEEE 802.11 b dapat dilihat seperti pada Gambar 3. 


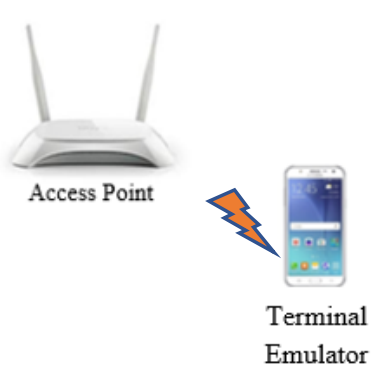

Gambar 3. Skenario Penelitian Tanpa VolP

\section{a. Skenario Penelitian}

- 1 unit perangkat hotspot yang akan memberikan akses ke Smartphone dan Laptop.

- Perangkat smartphone yang di-install terminal emulator untuk mengukur delay dan packet loss.

\subsubsection{Skenario Penelitian Tanpa Beban VolP}

Skenario penelitian pengukuran kinerja VolP dengan codec G.711 G.711a dan G.729 di Media transmisi nirkabel berbasis SIP dan IAX dapat dilihat seperti pada Gambar 4.

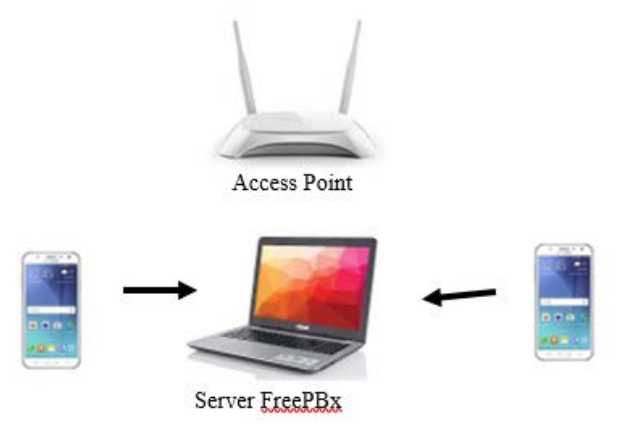

Gambar 4. Skenario Penelitian dengan VolP

\section{a. Skenario Penelitian I}

- 1 unit perangkat hotspot yang akan memberikan akses ke Smartphone dan Laptop.

- Perangkat laptop yang menjadi server dan diinstall FreePBx dengan softswitch (server) berbasis SIP .

- Perangkat smartphone yang diinstall softphone zoiper.

\section{b. Skenario Penelitian II}

- 1 unit perangkat hotspot yang akan memberikan akses ke Smartphone dan Laptop.
- Perangkat laptop yang menjadi server dan diinstall FreePBx dengan softswitch (server) berbasis IAX .

- Perangkat smartphone yang diinstall softphone zoiper.

\subsection{Alur Analisis}

\subsubsection{Alur Penelitian Umum}

Dalam menganalisa data menggunakan alur analisa yang disusun sesuai dengan langkah - langkah berbentuk diagram alir seperti pada Gambar 5.



Gambar 5. Diagram Alur Analisis Penelitian

Berdasarkan diagram alur analisis penelitian pada Gambar 5, sistem dimulai dengan memberikan inputan dengan mempelajari studi literature perangkat perangkat VolP dan juga parameter uji yaitu QoS. Selanjutnya menganalisa hasil pengukuran jaringan tanpa VoIP (IEEE 802.11 b) dan jaringan dengan VolP. Lalu membandingkan hasil QoS dengan standarisasi ITU-T. Setelah mendapatkan hasilnya, dilanjutkan dengan menganalisa dan membandingkan jaringan tanpa VolP (IEEE 802.11 b) dan jaringan dengan VolP dan didapatlah kesimpulan.

\section{HASIL DAN PEMBAHASAN}




\subsection{Hasil Penelitian}

Pengukuran kinerja (QoS) pada jaringan wireless ini dilakukan dengan dua aplikasi pengukuran, yaitu terminal emulator dan wireshark dengan jarak yang sudah ditentukan, yaitu pada jarak 5 meter, 10 meter, 15 meter, 20 meter, 25 meter dan 30 meter.

\subsubsection{Hasil QoS Jaringan Wireless IEEE 802.11 b}

a. Delay

Hasil dari delay pada jaringan wireless IEEE 802.11 b dapat dilihat pada Gambar 6. Besar delay yang dihasilkan pada jarak ke-5 meter adalah 3,611 ms dan pada jarak maksimal jaringan wireless, yaitu jarak ke-30 meter menghasilkan delay sebesar $117,524 \mathrm{~ms}$.

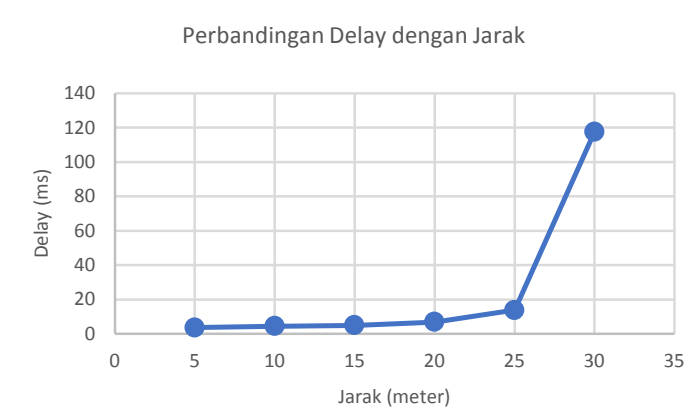

Gambar 6. Grafik Perbandingan Delay dengan Jarak

\section{b. Packet Loss}

Hasil dari packet loss pada jaringan wireless IEEE 802.11 b dapat dilihat pada Gambar 7. Besar packet loss yang dihasilkan pada jarak ke-5 meter sampai dengan jarak ke-30 meter adalah sebesar $0 \%$.

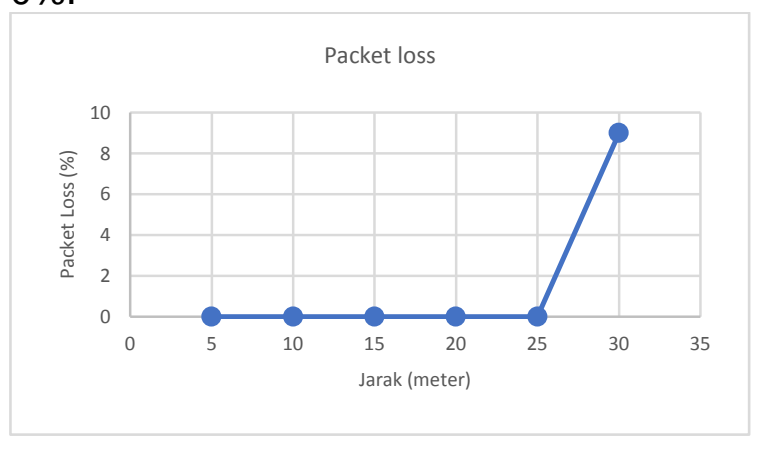

Gambar 7. Grafik Perbandingan Packet Loss dengan Jarak

\subsubsection{Perbandingan Hasil QoS dengan

 Berbasis SIP dan IAX \\ a. Delay}

Berdasarkan hasil delay dengan

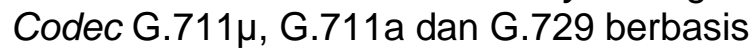
SIP dan IAX, maka dihasilkan perbandingan dari ketiga codec dengan server SIP dan IAX dapat dilihat pada Gambar 8.

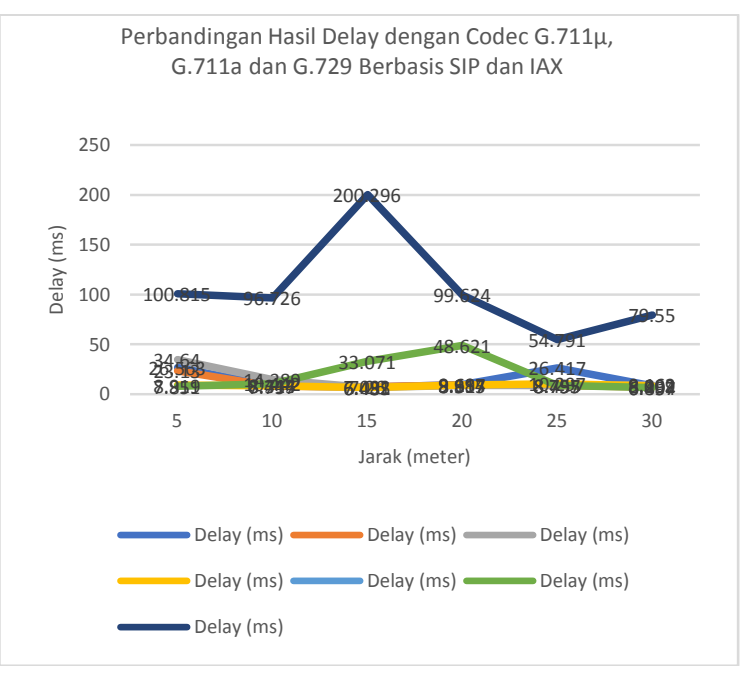


G.711a dan G.729 Berbasis SIP dan IAX

\section{b. Packet loss}

Berdasarkan hasil packet loss dengan Codec G.711 $\mu$, G.711a dan G.729 berbasis SIP dan IAX, maka dihasilkan perbandingan dari ketiga codec dengan server SIP dan IAX dapat dilihat seperti pada Gambar 9. 


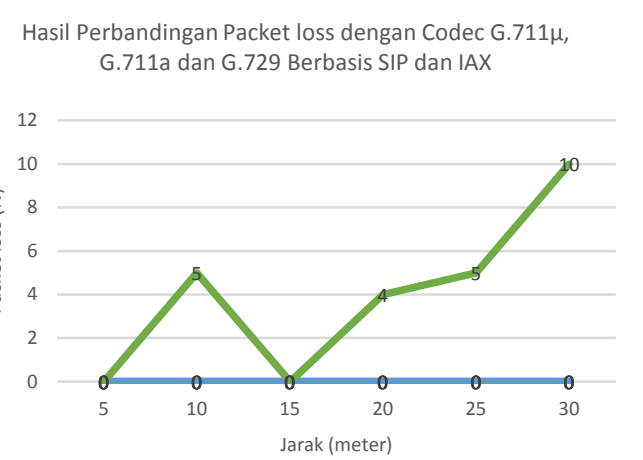

$\longrightarrow$ Packetloss (\%) Packetloss (\%) Packetloss (\%)

Packetloss (\%) Packetloss (\%) Packetloss (\%)

Gambar 9. Grafik Perbandingan Packet loss dengan Codec G.711 $\mu$, G.711a dan G.729 Berbasis SIP dan IAX

\section{c. Jitter}

Berdasarkan hasil jitter dengan

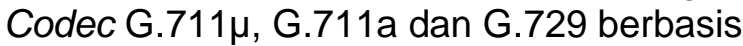
SIP dan IAX, maka dihasilkan perbandingan dari ketiga codec dengan server SIP dan IAX dapat dilihat seperti pada Gambar 10.



Gambar 10. Grafik Perbandingan Jitter dengan Codec G.711 $\mu$, G.711a dan G.729

Berbasis SIP dan IAX

\section{d. Mean Opinion Score (MOS)}

Berdasarkan hasil MOS dengan Codec G.711 $\mu$, G.711a dan G.729 berbasis SIP dan IAX, maka dihasilkan perbandingan dari ketiga codec dengan server SIP dan IAX dapat dilihat pada Tabel 6.
Tabel 6. Perbandingan MOS dengan Codec

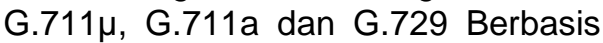
SIP dan IAX

\begin{tabular}{|c|c|c|c|c|c|c|c|}
\hline \multirow{2}{*}{ No } & \multirow{3}{*}{$\begin{array}{c}\text { Jarak } \\
\text { (meter) }\end{array}$} & \multicolumn{6}{|c|}{ MOS } \\
\cline { 3 - 8 } & & \multicolumn{3}{|c|}{ SIP } & \multicolumn{3}{|c|}{ IAX } \\
\cline { 3 - 8 } & & $\mathbf{G . 7 1 1 \mu}$ & G.711a & G.729 & G.711 $\boldsymbol{G}$ & G.711a & G.729 \\
\hline 1. & 5 & 3,5 & 3,7 & 3.0 & 4,2 & 4,2 & 1.0 \\
\hline 2. & 10 & 4,2 & 4,2 & 3,9 & 4,2 & 4,1 & 1.0 \\
\hline 3. & 15 & 4,2 & 4,2 & 4,2 & 4,2 & 3,2 & 1.0 \\
\hline 4. & 20 & 4,2 & 4,2 & 4,2 & 4,2 & 2,9 & 1.0 \\
\hline 5. & 25 & 3,5 & 4,2 & 4,2 & 4,1 & 4,2 & 2,0 \\
\hline 6. & 30 & 4,2 & 4,2 & 4,2 & 4,2 & 4,2 & 1,1 \\
\hline
\end{tabular}

\subsection{Pembahasan}

\subsubsection{Parameter Jaringan Wireless IEEE 802.11 b}

Pada penelitian ini, alokasi frekuensi yang digunakan yaitu frekuensi $2,4 \mathrm{GHz}$ untuk jaringan wireless IEEE 802.11 b dengan bit rate maksimum sebesar 11 Mbps. Untuk melihat parameter jaringan wireless 802.11 b, dapat dilihat pada Tabel 7.

Tabel 7. Parameter IEEE 802.11 b

\begin{tabular}{|l|l|c|}
\hline \multirow{2}{*}{ No. } & \multicolumn{1}{|c|}{ Statistik } & $\begin{array}{c}\text { Nilai } \\
\text { IEEE 802.11b } \\
\text { TP Link MR- 3420 }\end{array}$ \\
\hline 1 & $\begin{array}{l}\text { Receive Sensitivity } \\
\text { (dBm) }\end{array}$ & -62 \\
\hline 2 & Antenna Gain $(\mathrm{dBi})$ & 2 \\
\hline 3 & Frekuensi Band $(\mathrm{GHz})$ & 2,4 \\
\hline 4 & Tx cable loss $(\mathrm{dB})$ & 1 \\
\hline 5 & Transmit Power $(\mathrm{dBm})$ & 27 \\
\hline 6 & EIRP $(\mathrm{dBm})$ & 18 \\
\hline
\end{tabular}

Dalam melakukan perhitungan jarak yang dilakukan saat penelitian agar tidak melebihi jarak yang didapat maka dilakukanlah analisa hasil perhitungan jangkauan jarak yang mengacu pada bab II persamaan 2 dan persamaan 3 pada penelitian yang dilakukan secara LOS (Line Of Sight) pada Kampus Fakultas Teknik Universitas Udayana Sudirman adalah sebagai berikut : 


$$
\begin{aligned}
& F S L(\text { Free Space Loss })=T x \text { Power }-T x \text { cable loss } \\
& + \text { Tx antenna gain }+ \text { Rx antenna gain }- \text { Rx cable loss } \\
& \begin{aligned}
&-R x \text { Sensitivity }- \text { Fade Margin } \\
& F S L=27-1+2+ 2-1+62-0=91 \\
& 20 \log (d) \\
&=F S L-92,45-20 \log 10(f) \\
&=91-92,45-20 \log 10(2,4) \\
&=91-92,45-27,6 \\
&=-29,05 \quad \\
& \log (d)=\frac{-29,05}{20}=-1,4525 \\
& d=0,035 \mathrm{~km}= 35 \text { meter }
\end{aligned}
\end{aligned}
$$

Jarak jangkau dari jaringan wireless yang digunakan adalah kurang lebih 35 meter. Namun secara aktual, jarak jangkau yang didapat adalah maksimal 30 meter. Kemungkinan terjadi dikarenakan antena yang digunakan pada wireless adalah antenna omnidireksional (memancar ke segala arah). Walaupun digunakan dengan kondisi outdoor dan LOS (Line Of Sight), karena memancarkan sinyal ke segala arah, maka refleksi sinyal (pantulan sinyal) akan berpengaruh terhadap jarak.

\subsubsection{Delay}

Hasil dari delay pada jaringan wireless IEEE 802.11 b dapat dilihat pada Gambar 11. Besar delay yang dihasilkan pada jarak ke-5 meter adalah 3,611 ms dan pada jarak maksimal jaringan wireless, yaitu jarak ke-30 meter menghasilkan delay sebesar $117,524 \mathrm{~ms}$.

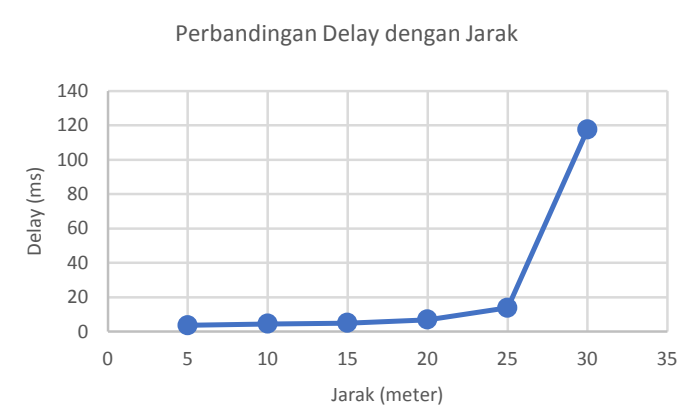

Gambar 11. Grafik Perbandingan Delay dengan Jarak

Pada kondisi jaringan wireless menggunakan antenna omnidireksional, sinyal yang datang menuju penerima telah mengalami pantulan dan redaman. Pantulan dan redaman tersebut menyebabkan perubahan fasa dan menimbulkan delay. Berdasarkan hasil grafik perbandingan jarak terhadap delay pada Gambar 6, dapat disimpulkan bahwa hasil dari delay pada jaringan IEEE 802.11 b linier, semakin jauh jarak maka delay yang dihasilkan semakin besar. Mengacu pada bab II dengan Tabel 1 menurut standar ITU-T, untuk delay (<150 ms) yang dihasilkan pada jaringan wireless IEEE 802.11 b termasuk dalam kategori kualitas baik.

\subsubsection{Packet Loss}

Hasil dari packet loss pada jaringan wireless IEEE 802.11 b dapat dilihat pada Gambar 12. Besar packet loss yang dihasilkan pada jarak ke-5 meter sampai dengan jarak ke-30 meter adalah sebesar 0\% yang menandakan bahwa paket yang dikirim, secara keseluruhan dapat diterima pada sisi penerima tanpa adanya paket yang terbuang. Packet loss terjadi karena adanya data yang menumpuk pada lajur yang dilewati saat overload yang menyebabkan metode packet transmisi mangalami kemacetan akibat padatnya trafik data yang dilayani dengan waktu yang terbatas.

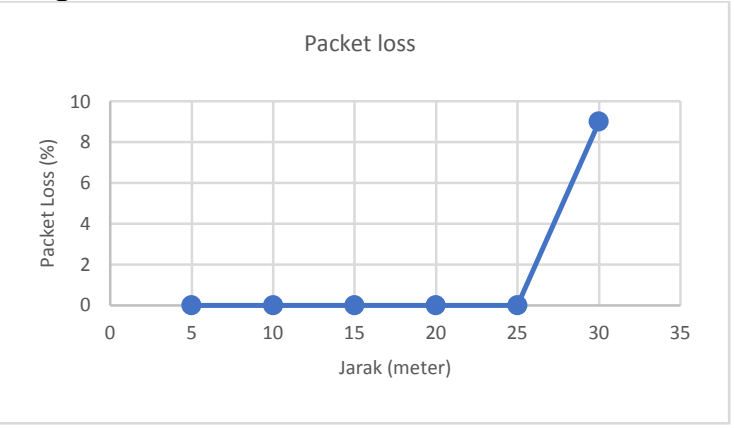

Gambar 12. Grafik Perbandingan Packet Loss dengan Jarak

Mengacu pada bab II dengan Tabel 3 menurut standar ITU-T, untuk packet loss yang dihasilkan pada jaringan wireless IEEE 802.11 b termasuk dalam kategori kualitas baik $(<0.5 \%)$, namun pada jarak 30 meter, packet loss yang dihasilkan termasuk dalam kategori kualitas buruk 
$(>1.5 \%)$ karena semakin jauh jarak maka packet loss yang dihasilkan juga besar.

\subsubsection{Perbandingan Hasil QoS dengan

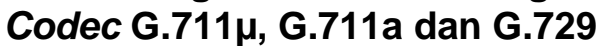 Berbasis SIP dan IAX}

\section{a. Delay}

Berdasarkan hasil delay dengan

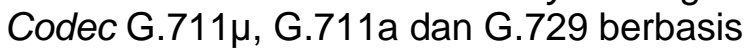
SIP dan IAX, maka dihasilkan perbandingan dari ketiga codec dengan server SIP dan IAX dapat dilihat pada Gambar 13.



Gambar 13. Grafik dengan Codec G.711 $\mu$, G.711a dan G.729 Berbasis SIP dan IAX

Hasil delay yang paling baik kualitasnya adalah codec G.711a pada server SIP dan codec G.711 $\mu$ pada server IAX. Jika mengacu pada teori, delay yang paling baik kualitasnya seharusnya pada codec G.729 karena bitrate pada codec G.729 sudah dikompresi menjadi 8 kbps, lebih kecil dibandingkan dengan codec G.711a maupun G.711 $\mu$ yang memiliki bitrate sebesar 64 kbps. Namun pada penelitian ini, codec G.711 memiliki kualitas paling baik. Hal itu dikarenakan codec G.711 memiliki bitrate yang sesuai dengan standar komunikasi suara, yaitu 64 kbps dan menggunakan teknik pengkodean suara yang sesuai dengan teknik pengkodean sinyal digital yaitu teknik PCM (Pulse Code Modulation).

\section{b. Packet loss}

Berdasarkan hasil packet loss dengan

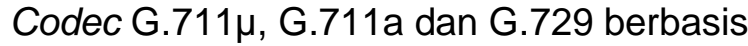
SIP dan IAX, maka dihasilkan perbandingan dari ketiga codec dengan server SIP dan IAX dapat dilihat pada Gambar 14

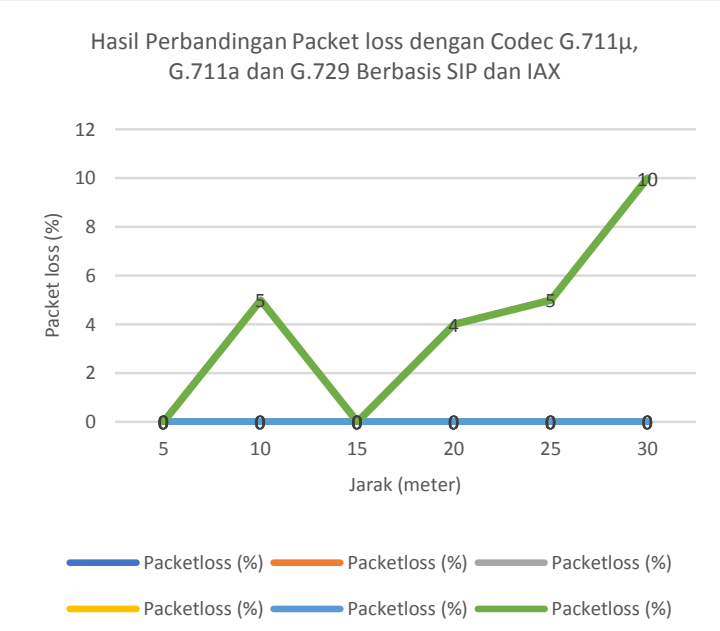

Gambar 14. Grafik Perbandingan Packet

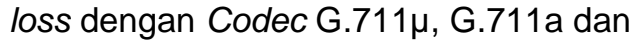
G.729 Berbasis SIP dan IAX

Hasil dari packet loss dengan codec

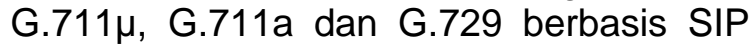
dan IAX memiliki hasil yang sama, namun codec G.729 pada server IAX menghasilkan packet loss yang besar. Hal itu dikarenakan pada saat melakukan proses komunikasi menggunakan codec G.729 pada server IAX, suara yang dihasilkan terputus - putus dan menyebabkan packet loss pada codec G.729 server IAX besar.

Packet loss terjadi karena adanya data yang menumpuk pada lajur yang dilewati saat overload yang menyebabkan metode packet transmisi mangalami kemacetan akibat padatnya trafik data yang dilayani dengan waktu yang terbatas. .

\section{c. Jitter}

Berdasarkan hasil jitter dengan Codec G.711 $\mu$, G.711a dan G.729 berbasis SIP dan IAX, maka dihasilkan perbandingan 
dari ketiga codec dengan server SIP dan IAX dapat dilihat pada Gambar 15.

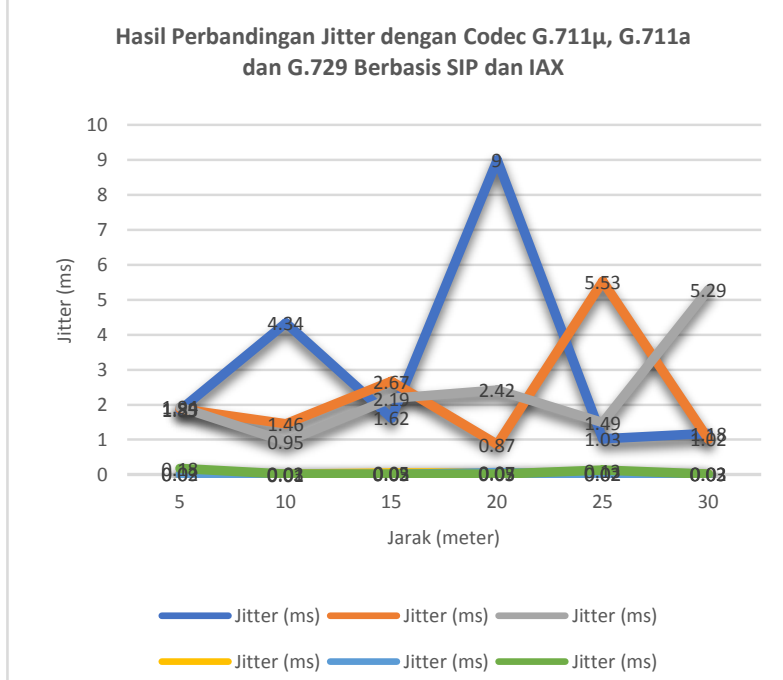

Gambar 15. Grafik Perbandingan Jitter dengan Codec G.711 $\mu$, G.711a dan G.729 Berbasis SIP dan IAX

Hasil dari jitter dengan codec G.711 $\mu$, G.711a dan G.729 berbasis SIP dan IAX. Hasil jitter yang paling baik kualitasnya adalah codec G.711a pada server SIP dan codec G.711 $\mu$ pada server IAX. Jika mengacu pada teori, jitter yang paling baik kualitasnya seharusnya pada codec G.729 karena bitrate pada codec G.729 sudah dikompresi menjadi 8 kbps, lebih kecil dibandingkan dengan codec G.711a maupun G.711 $\mu$ yang memiliki bitrate sebesar $64 \mathrm{kbps}$. Namun pada penelitian ini, codec G.711 memiliki kualitas paling baik. Hal itu dikarenakan codec G.711 memiliki bitrate yang sesuai dengan standar komunikasi suara, yaitu 64 kbps dan menggunakan teknik pengkodean suara yang sesuai dengan teknik pengkodean sinyal digital yaitu teknik PCM (Pulse Code Modulation).

\section{d. Mean Opinion Score (MOS)}

Berdasarkan hasil MOS dengan Codec

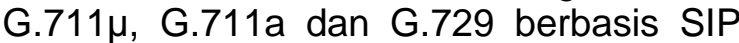
dan IAX, maka dihasilkan perbandingan dari ketiga codec dengan server SIP dan IAX dapat dilihat pada Tabel 8.
Tabel 8. Perbandingan MOS dengan Codec


SIP dan IAX

\begin{tabular}{|c|c|c|c|c|c|c|c|}
\hline \multirow{3}{*}{ No } & \multirow{3}{*}{$\begin{array}{c}\text { Jarak } \\
\text { (meter) }\end{array}$} & \multicolumn{6}{|c|}{ MOS } \\
\hline & & \multicolumn{3}{|c|}{ SIP } & \multicolumn{3}{|c|}{ IAX } \\
\hline & & G.711 $\mu$ & G.711a & G.729 & G.711 $\mu$ & G.711a & G.729 \\
\hline 1. & 5 & 3,5 & 3,7 & 3.0 & 4,2 & 4,2 & 1.0 \\
\hline 2. & 10 & 4,2 & 4,2 & 3,9 & 4,2 & 4,1 & 1.0 \\
\hline 3. & 15 & 4,2 & 4,2 & 4,2 & 4,2 & 3,2 & 1.0 \\
\hline 4. & 20 & 4,2 & 4,2 & 4,2 & 4,2 & 2,9 & 1.0 \\
\hline 5. & 25 & 3,5 & 4,2 & 4,2 & 4,1 & 4,2 & 2,0 \\
\hline 6. & 30 & 4,2 & 4,2 & 4,2 & 4,2 & 4,2 & 1,1 \\
\hline
\end{tabular}

Hasil dari MOS dengan codec G.711 $\mu$, G.711a dan G.729 berbasis SIP dan IAX. Hasil MOS yang paling baik kualitasnya adalah codec G.711a pada server SIP dan codec G.711 $\mu$ pada server IAX.

Jika mengacu pada teori, MOS yang paling baik kualitasnya seharusnya pada codec G.729 karena bitrate pada codec G.729 sudah dikompresi menjadi 8 kbps, lebih kecil dibandingkan dengan codec G.711a maupun $\mathrm{G} .711 \mu$ yang memiliki bitrate sebesar 64 kbps. Namun pada penelitian ini, codec G.711 memiliki kualitas paling baik. Hal itu dikarenakan codec G.711 memiliki bitrate yang sesuai dengan standar komunikasi suara, yaitu 64 kbps dan menggunakan teknik pengkodean suara yang sesuai dengan teknik pengkodean sinyal digital yaitu teknik PCM (Pulse Code Modulation).

\section{SIMPULAN}

Simpulan yang dapat ditarik dari pada penelitian ini adalah jarak jangkau dari jaringan wireless secara teoritis adalah 35 meter. Namun secara aktual, jarak jangkau yang didapat adalah maksimal 30 meter. Kemungkinan terjadi dikarenakan antena yang digunakan pada wireless adalah antenna omnidireksional (memancar ke segala arah). Walaupun digunakan dengan kondisi outdoor dan LOS (Line Of Sight), karena memancarkan sinyal ke segala arah, maka refleksi sinyal (pantulan sinyal) akan berpengaruh terhadap jarak.

QoS (Quality of Service) pada wireless IEEE 802.11 b memiliki hasil yang linear, sedangkan QoS pada wireless yang terbebani VolP memiliki hasil fluktuatif karena penggunaan codec pada VoIP yang 
mana masing-masing codec memiliki besar bitrate dan teknik pengkodean yang berbeda.

QoS (Quality of Service) pada codec

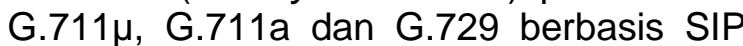
dan IAX memiliki hasil fluktuatif yang merupakan ciri dari jaringan nirkabel. Pada hasil penelitian, codec G.711 menghasilkan kualitas QoS paling baik. Hal itu dikarenakan codec G.711 memiliki bitrate yang sesuai standar komunikasi suara (64 kbps) yang berarti suara yang dihasilkan tidak dilakukan teknik kompresi dan menggunakan teknik pengkodean suara yang sesuai dengan teknik pengkodean sinyal digital yaitu teknik PCM (Pulse Code Modulation).

\section{DAFTAR PUSTAKA}

[1] Supriyanto, Aji. 2006. Tinjauan Teknis Teknologi Perangkat Wireless dan Standar Keamanannya. Jurnal Teknologi Informasi DINAMIK Vol:11, No:75-83.

[2] Agung Indra Prasetya, AAN, N. Gunantara, N. dan Sudiarta, P.K.. 2017. Analisis Propagasi Indoor WLAN 802.11g pada Gedung Dishubkominfo Kabupaten Badung. EJournal SPEKTRUM Vol. 4, No. 2 Desember 2017.

[3] Gunantara, N., Sudiarta, P. K., Prasetya, AAN A. I. Dharma, A. dan Antara, I N. G. 2018. Measurements of the Received Signal Level and Service Coverage Area at the IEEE 802.11 Access Point in the Building. Journal of Physics Conference Series Vol. 989

[4] Irwansyah, E. \& Jurike V, M,. 2014. Pengantar Teknologi Informasi. Yogyakarta : Deepublish.

[5] Purbo, W.O. 2006. Buku Pegangan Internet Wireless dan Hotspot. Elex Media Komputindo. Jakarta.

[6] McLeod, Raymond. dan Schell, G.P. 2008. Sistem Informasi Manajemen edisi 10. Jakarta : Salemba Empat.

[7] Tharom, Tabratas. 2002. Teknis dan Bisnis VolP. Jakarta : PT. Elex Media Komputindo.

[8] Zein, R.O. 2016. "Analisis Layanan
VoIP pada Jaringan MANET dengan Codec yang Berbeda" (tugas akhir). Denpasar: Universitas Udayana.

[9] Aliwi, H.S.H, Alomari, A.S. dan Sumari, Putra. 2011. An Effective Method For Audio Translation between IAX and RSW Protocols. International Journal of Electrical and Computer Engineering Vol:5, No:11.

[10] ITU-T. 2003. SERIES G: TRANSMISSION SYSTEMS AND MEDIA, DIGITAL SYSTEMS AND NETWORKS. ITU-T Recommendation G.114.

[11] ITU-T. 1998. The E-Model, a computational model for use in transmission planning. ITU-T Recommendation G.107.

[12] ITU-T. 1996. Methods for Subjective Determination of Transmission Quality. ITU-T Recommendation P.800.

[13] Manurung, A.F. \& Mubarakah, Naemah. 2014. Analisis Link Budget untuk Koneksi Radio Wireless Local Area Network (Wlan) 802.11b dengan menggunakan Simulasi Radio Mobile (Studi Kasus Pada Jalan Kartini Siantar - Ambarisan). Singuda Ensikom Vol:7, No:2. 